University of Nebraska - Lincoln

DigitalCommons@University of Nebraska - Lincoln

Biological Systems Engineering: Papers and

Publications

Biological Systems Engineering

$7-2013$

\title{
NARROW GRASS HEDGE EFFECTS ON NUTRIENT TRANSPORT FOLLOWING SWINE SLURRY APPLICATION
}

John E. Gilley

Adjunct Professor, Biological Systems Engineering, john.gilley@ars.usda.gov

Shannon L. Bartelt-Hunt

University of Nebraska-Lincoln, sbartelt2@unl.edu

Seth J. Lamb

University of Nebraska-Lincoln

Xu Li

University of Nebraska-Lincoln, xuli@unl.edu

David B. Marx

University of Nebraska-Lincoln, david.marx@unl.edu

See next page for additional authors

Follow this and additional works at: https://digitalcommons.unl.edu/biosysengfacpub

Part of the Bioresource and Agricultural Engineering Commons

Gilley, John E.; Bartelt-Hunt, Shannon L.; Lamb, Seth J.; Li, Xu; Marx, David B.; Snow, Daniel D.; Parker, David B.; and Woodbury, Brian L., "NARROW GRASS HEDGE EFFECTS ON NUTRIENT TRANSPORT FOLLOWING SWINE SLURRY APPLICATION" (2013). Biological Systems Engineering: Papers and Publications. 325.

https://digitalcommons.unl.edu/biosysengfacpub/325

This Article is brought to you for free and open access by the Biological Systems Engineering at DigitalCommons@University of Nebraska - Lincoln. It has been accepted for inclusion in Biological Systems Engineering: Papers and Publications by an authorized administrator of DigitalCommons@University of Nebraska Lincoln. 


\section{Authors}

John E. Gilley, Shannon L. Bartelt-Hunt, Seth J. Lamb, Xu Li, David B. Marx, Daniel D. Snow, David B. Parker, and Brian L. Woodbury 


\title{
NARROW GRASS HEDGE EFFECTS ON NUTRIENT TRANSPORT FOLLOWING SWINE SLURRY APPLICATION
}

\author{
J. E. Gilley, S. L. Bartelt-Hunt, S. J. Lamb, X. Li, D. B. Marx, \\ D. D. Snow, D. B. Parker, B. L. Woodbury
}

\begin{abstract}
The effectiveness of a narrow grass hedge in reducing runoff nutrient loads following swine slurry application was examined. Slurry was applied to $0.75 \mathrm{~m}$ wide by $4.0 \mathrm{~m}$ long plots established on an Aksarben silty clay loam soil located in southeast Nebraska. Manure treatments consisted of no manure application and manure application to meet the 1, 2, or 3 year nitrogen (N) requirements for corn. Runoff water quality was measured during three 30 min simulated rainfall events. The grass hedge did not significantly reduce runoff nutrient transport after the swine slurry, which contained relatively small amounts of manure, was applied. Increasing the $N$ application rate from a 1 year to a 3 year corn $N$ requirement also did not result in a significant increase in $N$ or phosphorus $(P)$ loads in runoff. The grass hedge significantly reduced electrical conductivity (EC) measurements from 0.78 to $0.73 \mathrm{dS} \mathrm{m}^{-1}$ and $\mathrm{pH}$ values from 8.16 to 7.85. The rates of transport of dissolved $P$, particulate $P$, and total $P$ were each influenced by runoff rate and increased in $a$ linear fashion from 7 to 25, 65 to 357, and 72 to $382 \mathrm{~g} \mathrm{ha}^{-1} \mathrm{~min}^{-1}$, respectively. Runoff rate significantly affected rates of transport of $\mathrm{NO}_{3}-\mathrm{N}, \mathrm{NH}_{4}-\mathrm{N}$, and total nitrogen, which increased in a linear fashion from 273 to 1204, 30 to 47, and 323 to $1490 \mathrm{~g} \mathrm{ha}^{-1} \mathrm{~min}^{-1}$, respectively. Runoff rate is an important variable that should be considered when estimating nutrient transport following application of swine slurry containing relatively small amounts of nutrients.
\end{abstract}

Keywords. Grass filters, Land application, Manure management, Manure runoff, Nitrogen, Nutrients, Phosphorus, Runoff, Soil loss, Water quality.

$\mathrm{M}$ anure can be effectively used for crop production and soil improvement because it contains nutrients and organic matter (Eghball and Power, 1994). Runoff and erosion have been reduced significantly on sites receiving long-term manure application at appropriate rates (Gilley and Risse, 2000). An increase in soil nutrient content may result in greater runoff nutrient concentrations (Gilley et al.,

Submitted for review in January 2013 as manuscript number SW 10105; approved for publication by the Soil \& Water Division of ASABE in May 2013.

This article is a contribution from the USDA-ARS in cooperation with the Agricultural Research Division, University of Nebraska, Lincoln, Nebraska.

Mention of company or trade names is for description only and does not imply endorsement by the USDA. The USDA is an equal opportunity provider and employer.

The authors are John E. Gilley, ASABE Member, Research Agricultural Engineer, USDA-ARS, Lincoln, Nebraska; Shannon L. Bartelt-Hunt, Associate Professor, Department of Civil Engineering, University of Nebraska, Omaha, Nebraska; Seth J. Lamb, Former Graduate Student, Department of Environmental Engineering, $\mathbf{X u ~} \mathbf{L i}$, Assistant Professor, Department of Civil Engineering, David B. Marx, Professor, Department of Statistics, and Daniel D. Snow, Research Associate Professor, Water Center, University of Nebraska, Lincoln, Nebraska; David B. Parker, ASABE Member, Director, Commercial Core Laboratory, West Texas A\&M University, Canyon, Texas; and Bryan L. Woodbury, ASABE Member, Research Agricultural Engineer, USDAARS U.S. Meat Animal Research Center, Clay Center, Nebraska. Corresponding author: John E. Gilley, USDA-ARS, 251 Chase Hall, University of Nebraska, Lincoln, NE 68583-0934; phone: 402-472-2975; e-mail: John.Gilley@ars.usda.gov. 2007a). However, soil nutrient values on cropland may not significantly impact nutrient losses when rainfall occurs soon after manure application (Eghball et al., 2002).

Placement of narrow grass hedges along the slope contour provides several benefits (Dewald et al., 1996; Jin and Romkens, 2000; Kemper et al., 1992). Improved soil hydraulic properties beneath grass hedges help to enhance infiltration and reduce runoff (Rachman et al., 2004a, 2004b). Runoff nutrient losses are reduced significantly by narrow grass hedges (Eghball et al., 2000; Owino et al., 2006). Narrow grass hedges also promote sediment deposition and berm formation as well as diffuse and spread overland flow (Dabney et al., 1995, 1999).

Sediment trapping by narrow grass hedges results primarily from upslope ponding by the hedges (Meyer et al., 1995). The placement of narrow grass hedges at selected intervals along a hillslope causes much of the sediment carried by overland flow to move only a short distance before it is deposited. Narrow grass hedges are planted at short distances along the slope contour that allow multiple passes of farm implements (Meyer et al., 1995; Dewald et al., 1996). The horizontal spacing between narrow grass hedges is determined using the lesser of: (a) the horizontal distance where the change in vertical elevation is $2 \mathrm{~m}$, or (b) the RUSLE 2 (Renard et al., 1997) " $L$ " value that restricts soil loss from the field to the allowed limit (USDA-NRCS, 2010).

It is recommended that narrow grass hedge width (flow path through the hedge) be the larger of: (a) $1 \mathrm{~m}$, or 
(b) 0.75 times the change in upslope vertical elevation (USDA-NRCS, 2010). Broadcast or drilled seed should be sown in strips at least $1 \mathrm{~m}$ wide. Grass hedges seeded with a row planter should be at least two rows wide.

Narrow grass hedges have been effectively used in combination with vegetative filter strips (Blanco-Canqui et al., 2004a). When placed immediately above vegetative filter strips, narrow grass hedges minimized soil and nutrient losses resulting from interrill and concentrated flow (Blanco-Canqui et al., 2004b, 2006).

\section{USE OF NaRrow Grass Hedges ON LAND APPLICATION AREAS}

Gilley et al. (2008a) conducted a field study to measure the effectiveness of a narrow grass hedge in reducing runoff nutrient transport from plots with a range of soil nutrient values. Varying amounts of composted beef cattle manure were applied to a silty clay loam soil located at the Rogers Memorial Farm near Lincoln, Nebraska, and then incorporated by disking. Rainfall simulation tests were conducted several months later to measure nutrient transport from $0.75 \mathrm{~m}$ wide $\times 4.0 \mathrm{~m}$ long plots. The grass hedges significantly reduced the transport of dissolved phosphorus (DP) and total phosphorus (TP) in runoff. When averaged across compost application rates, the $0.20 \mathrm{~kg} \mathrm{NO}_{3}-\mathrm{N} \mathrm{ha}^{-1}$ contained in runoff from the grass hedge treatment was significantly less than the $0.62 \mathrm{~kg} \mathrm{ha}^{-1}$ measured from the no-hedge treatment. The grass hedge also decreased total nitrogen (TN) transport in runoff from $7.62 \mathrm{~kg} \mathrm{ha}^{-1}$ on the no-hedge treatment to $4.00 \mathrm{~kg} \mathrm{ha}^{-1}$ on the plots with a grass hedge. The experimental results indicated that grass hedges can significantly reduce the transport of nutrients in runoff from areas with a range of soil nutrient values.

The effectiveness of a narrow grass hedge in reducing runoff nutrient loads occurring soon after the application of beef cattle manure was examined by Gilley et al. (2011). Beef cattle manure was applied to $0.75 \mathrm{~m}$ wide $\times$ $4.0 \mathrm{~m}$ long plots located at the Rogers Memorial Farm near Lincoln, Nebraska. Manure was added at rates required to meet none or the 1,2 , or 4 year nitrogen $(\mathrm{N})$ requirements for corn. Rainfall simulation tests were conducted to measure runoff nutrient transport. The grass hedge reduced the mean load of DP in runoff from 0.69 to $0.08 \mathrm{~kg} \mathrm{ha}^{-1}$ and the load of TP from 1.05 to $0.13 \mathrm{~kg} \mathrm{ha}^{-1}$. For the plots with a grass hedge, runoff loads of DP and TP where beef cattle manure was applied were similar to values obtained with no manure application. When averaged across manure application rates, $0.11 \mathrm{~kg} \mathrm{NO}_{3}-\mathrm{N}$ $\mathrm{ha}^{-1}, 0.02 \mathrm{~kg} \mathrm{NH}_{4}-\mathrm{N} \mathrm{ha}{ }^{-1}$, and $0.49 \mathrm{~kg} \mathrm{TN} \mathrm{ha}{ }^{-1}$ were measured from the plots with a hedge, compared to 0.39 $\mathrm{kg} \mathrm{NO}_{3}-\mathrm{N} \mathrm{ha}^{-1}, 0.55 \mathrm{~kg} \mathrm{NH}_{4}-\mathrm{N} \mathrm{ha}^{-1}$, and $2.52 \mathrm{~kg} \mathrm{TN} \mathrm{ha}^{-1}$ from the plots without a hedge. Thus, the narrow grass hedge significantly reduced runoff loads occurring soon after the application of beef cattle manure.

The objectives of this study were to (a) determine the effects of a narrow grass hedge and varying swine slurry application rates on runoff nutrient loads (mass per unit area) occurring soon after manure application, and (b) compare the effects of a narrow grass hedge, varying swine slurry application rates, and selected runoff rates on nutrient transport rates (mass per unit area per unit time).

\section{MATERIALS AND MethodS}

\section{STUdY Site ChaRACTERISTICS}

This field study was conducted at the University of Nebraska Rogers Memorial Farm located $18 \mathrm{~km}$ east of Lincoln, Nebraska. The soil at the site developed in loess under prairie vegetation. The Aksarben silty clay loam (fine, smectitic, mesic Typic Argiudoll) contained 16\% sand, $54 \%$ silt, and $30 \%$ clay (Kettler et al., 2001). The organic matter and total carbon content of the soil were $4 \%$ and $2.14 \%$, respectively.

The study site had been cropped using a long-term notill management system with controlled wheel traffic. Corn (Zea mays) was planted during the 2010 season, and herbicide (glyphosate) was applied as needed to control weed growth on the plot areas that were not covered by a grass hedge. Special care was taken so that herbicide was not applied to the grass hedge area.

Soil samples for study site characterization were obtained from the surface down to $2 \mathrm{~cm}$ just prior to manure application, and the soil samples were air-dried following collection. Mean measured concentrations of Bray and Kurtz No. $1 \mathrm{P}$, water-soluble $\mathrm{P}, \mathrm{NO}_{3}-\mathrm{N}$, and $\mathrm{NH}_{4}$ $\mathrm{N}$ were 15 (standard deviation (SD) 2.8), 1.6 (SD 0.085), 11 (SD 3.1), and 2 (SD 0.1) $\mathrm{mg} \mathrm{kg}^{-1}$, respectively. The soil at the study site had a mean electrical conductivity (EC) of $0.40(\mathrm{SD} 0.042) \mathrm{dS} \mathrm{m}^{-1}$ and a $\mathrm{pH}$ of 7.2 (SD 0.26).

\section{Plot Preparation}

Narrow grass hedges were established during 1998 in parallel rows following the contour of the land. A specialized grass drill was used in the seeding operation. The grass hedges were spaced at intervals along the hillslope that allowed multiple passes of tillage equipment. The narrow grass hedges were part of a strip-cropping system, and row crops were planted between the hedges. Mean slope gradient at the study site was $3.6 \%$.

Twenty-four $0.75 \mathrm{~m} \times 4.0 \mathrm{~m}$ plots were established with the $4.0 \mathrm{~m}$ plot dimension parallel to the slope in the direction of overland flow. Experimental treatments included the presence or absence within the plot of a $1.4 \mathrm{~m}$ wide switchgrass (Panicum virgatum) hedge, varying manure application rates, and different runoff rates. The existence or absence of a grass hedge was the main plot treatment, and manure application rate was the subplot treatment (fig. 1). Calculations of nutrient load per unit area included the section covered by the hedge.

Field tests were conducted on six plots each week from July 6 to July 28,2011 . Tests were performed on plots 401 to 502 during week 1, plots 503 to 604 during week 2, plots 701 to 802 during week 3, and plots 803 to 904 during week 4 (fig. 1). Swine slurry was collected from the USDA Meat Animal Research Center near Clay Center, Nebraska, each week just prior to field application. Rainfall simulation tests were conducted soon after slurry application. 


\begin{tabular}{|c|c|c|c|}
\hline No-Hedge & No-Hedge & No-Hedge & No-Hedge \\
\hline Rate 2 & Rate 1 & Rate 0 & Rate 3 \\
\hline Plot 401 & Plot 402 & Plot 403 & Plot 404 \\
\hline No-Hedge & No-Hedge & No-Hedge & No-Hedge \\
\hline Rate 2 & Rate 0 & Rate 1 & Rate 3 \\
\hline Plot 501 & Plot 502 & Plot 503 & Plot 504 \\
\hline No-Hedge & No-Hedge & No-Hedge & No-Hedge \\
\hline Rate 1 & Rate 2 & Rate 0 & Rate 3 \\
\hline Plot 601 & Plot 602 & Plot 603 & Plot 604 \\
\hline With-Hedge & With-Hedge & With-Hedge & With-Hedge \\
\hline Rate 2 & Rate 1 & Rate 0 & Rate 3 \\
\hline Plot 701 & Plot 702 & Plot 703 & Plot 704 \\
\hline With-Hedge & With-Hedge & With-Hedge & With-Hedge \\
\hline Rate 2 & Rate 1 & Rate 3 & Rate 0 \\
\hline Plot 801 & Plot 802 & Plot 803 & Plot 804 \\
\hline With-Hedge & With-Hedge & With-Hedge & With-Hedge \\
\hline Rate 2 & Rate 0 & Rate 1 & Rate 3 \\
\hline Plot 901 & Plot 902 & Plot 903 & Plot 904 \\
\hline
\end{tabular}

Figure 1. Schematic showing the plot layout, hedge and no-hedge treatments, and nitrogen application rates based on $0,1,2$, or 3 year corn $\mathrm{N}$ requirements.

Slurry was obtained from a mechanically ventilated barn $(14 \mathrm{~m} \times 59 \mathrm{~m})$ that was stocked with finisher pigs (mass range 68 to $120 \mathrm{~kg}$ ). The pigs were fed a corn and soybean based diet. The building had a pull-plug waste management system that was partially filled with water to a $0.5 \mathrm{~m}$ depth. The swine slurry was collected each week from near the bottom of the pit using a submersible sewage pump. The slurry was pumped into $20 \mathrm{~L}$ plastic buckets and then transported to the field site. A subsample of the swine slurry was analyzed for solids and nutrients at a commercial laboratory. The $\mathrm{NO}_{3}-\mathrm{N}, \mathrm{NH}_{4}-\mathrm{N}, \mathrm{TN}, \mathrm{TP}$, dry matter content, $\mathrm{EC}$, and $\mathrm{pH}$ of the swine slurry were: 0.5 (SD 0.38) $\mathrm{mg} \mathrm{kg}^{-1}, 776$ (SD 180.8) $\mathrm{mg} \mathrm{kg}^{-1}, 923$ (SD 265.4) $\mathrm{mg} \mathrm{kg}^{-1}, 144$ (SD 55.6) $\mathrm{mg} \mathrm{kg}^{-1}, 0.44 \%$ (SD 0.175\%), 8.25 (SD 1.615) dS m ${ }^{-1}$, and 7.3 (SD 0.21), respectively.

Manure was applied in amounts required to meet none or the 1,2 , or 3 year $\mathrm{N}$ requirements for corn $(151 \mathrm{~kg} \mathrm{~N}$ ha ${ }^{1}$ year $^{-1}$ for an expected yield of $9.4 \mathrm{Mg} \mathrm{ha}^{-1}$ ) (fig. 1). When calculating manure application rates, it was assumed that the $\mathrm{N}$ availability from swine slurry was $70 \%$ of the total amount of nitrogen measured in the slurry (Gilbertson et al., 1979).

\section{Rainfall Simulation Procedures}

Water used in the rainfall simulation tests was obtained from an irrigation well. Nutrient contents reported in this article are the difference between nutrient measurements in runoff and those in the irrigation water. Measured mean concentrations of DP, TP, $\mathrm{NO}_{3}-\mathrm{N}, \mathrm{NH}_{4}-\mathrm{N}$, and $\mathrm{TN}$ in the irrigation water were: 0.19 (SD 0.019), 0.19 (SD 0.019), 15.6 (SD 0.47), 0.00 (SD 0.008), and 15.6 (SD 0.47) $\mathrm{mg} \mathrm{L}^{-1}$, respectively. The irrigation water had a mean EC of 0.77 (SD $0.014) \mathrm{dS} \mathrm{m}^{-1}$ and a pH of 7.2 (SD 0.21).

Rainfall simulation procedures established by the National Phosphorus Research Project were used in this study (Sharpley and Kleinman, 2003). A portable rainfall simulator based on the design by Humphry et al. (2002) was used to apply rainfall to paired plots. Two rain gauges were placed along the outer edge of each plot, and one rain gauge was located between the plots. Water was first added to the plots with a hose until runoff began, providing more uniform antecedent soil water conditions. The simulator was then used to apply rainfall for $30 \mathrm{~min}$ at an intensity of $70 \mathrm{~mm} \mathrm{~h}^{-1}$. Two additional rainfall simulation tests were conducted on the same plot for the same duration and intensity at approximately $24 \mathrm{~h}$ intervals.

Plot borders channeled runoff into a sheet metal lip that emptied into a collection trough located across the down gradient border of each plot. The trough diverted runoff into plastic buckets. A sump pump was then used to transfer runoff from the plastic buckets into larger plastic storage containers. The storage containers were weighed at the completion of each test to determine the total mass of runoff. Accumulated runoff was agitated to maintain suspension of solids. One runoff sample was collected for water quality analysis, and an additional sample was obtained for sediment analysis.

Centrifuged and filtered runoff samples of a known volume were analyzed for DP (Murphy and Riley, 1962) and $\mathrm{NO}_{3}-\mathrm{N}$ and $\mathrm{NH}_{4}-\mathrm{N}$ using a Lachat system (Zellweger Analytics, Milwaukee, Wisc.). Samples that were not centrifuged were analyzed for TP (Johnson and Ulrich, 1959), TN (Tate, 1994), pH, and EC. The samples of a known volume obtained for sediment analysis were dried in an oven at $105^{\circ} \mathrm{C}$ until all of the water had evaporated (approx. 2 days) and then weighed to determine sediment content.

The solids transported in runoff contained both sediment and a relatively small amount of material originating from the slurry that had been land applied. Some of the organic materials transported in runoff were lost during the drying process. After the drying process was completed, it was assumed that the amount of material that originated from the slurry was minimal, and the solids remaining in the plastic bottles were referred to as soil loss.

The upslope areas contributing runoff to grass hedges under typical field conditions are much larger than those employed in this study. Runoff quantities entering the grass hedges increase as the upslope contributing area becomes larger. Therefore, additional field tests were conducted to identify the effects of varying flow rate on nutrient transport. Water was added to the test plots to simulate increased flow rates resulting from larger upslope contributing areas. The addition of inflow to test plots to simulate greater slope lengths is a well-established experimental procedure (Monke et al., 1977; Laflen et al., 1991). 
Simulated overland flow was applied at the upgradient end of each plot after the third simulation run, while rainfall application continued at a rate of $70 \mathrm{~mm} \mathrm{~h}^{-1}$. Inflow was added in four successive increments to produce average runoff rates of $2.7,6.4,12.7$, and $19.4 \mathrm{~L} \mathrm{~min}^{-1}$ on the plots with a grass hedge and 4.6, 10.6, 14.8, and $19.9 \mathrm{~L}$ $\mathrm{min}^{-1}$ on the plots without a hedge. Greater infiltration rates within the plots containing a grass hedge resulted in smaller runoff rates. A narrow mat made of green synthetic material often used as outdoor carpet was placed on the soil surface beneath the inflow device. The mat helped to prevent scouring and distributed the flow more uniformly across the plot surface.

A mean overland flow rate of $0.73 \mathrm{~L} \mathrm{~min}^{-1}$ was measured without the addition of simulated overland flow. The largest mean overland flow rate was $19.7 \mathrm{~L} \mathrm{~min}^{-1}$, or approximately 27 times the value without the addition of inflow. The use of runoff quantities substantially larger than 19.7 $\mathrm{L} \mathrm{min}^{-1}$ did not seem reasonable for the size of the plots used in this study. Three additional intermediate simulated overland flow quantities were selected to provide overland flow rates useful for comparison.

Runoff was diverted into a flume where a stage recorder was mounted to measure flow rate. Flow addition for each simulated overland flow increment occurred only after steady runoff conditions had been reached for the previous increment and samples for nutrient and sediment analyses had been collected. Steady runoff conditions were determined using the stage recorder and flume. Each simulated overland flow increment was maintained for approximately 8 min.

\section{STATISTICAL ANALYSES}

Analysis of variance (SAS, 2011) was performed to determine the effects of a narrow grass hedge and nitrogen application rate on runoff nutrient load and the effects of a narrow grass hedge, nitrogen application rate, and simulated overland flow rate on the nutrient transport rate. If a significant difference was identified, the least significant difference (LSD) test was used to identify differences among experimental treatments. A probability level of $\leq 0.05$ was considered significant.

\section{RESULTS AND DISCUSSION}

\section{PhOSPHORUS LOAD IN RUNOFF}

The grass hedge did not significantly reduce runoff loads of DP, particulate phosphorus (PP), or TP, which for the grass hedge were $0.03,0.16$, and $0.19 \mathrm{~kg} \mathrm{ha}^{-1}$, respectively (table 1). Runoff loads of DP increased in a linear fashion with nitrogen application rate, and they were significantly larger on the plots where slurry was applied than on the check plots (fig. 2). However, increasing N application rate from a 1 year to a 3 year corn $\mathrm{N}$ requirement also did not result in a significant increase in DP, PP, or TP loads in runoff (table 1).

Runoff loads of PP were significantly greater on the plots where no slurry was applied than on the plots where slurry was added to meet the 2 or 3 year $\mathrm{N}$ requirements for corn (table 1). Runoff loads of PP are influenced by runoff rates. Larger amounts of slurry were applied as $\mathrm{N}$ application rates increased. The organic materials contained in the slurry may have helped to maintain higher infiltration rates and reduce runoff rates. Thus, the larger runoff rates occurring on the plots where less slurry was applied may have influenced the larger PP loads measured in runoff.

Slurry was obtained from this location because the swine diet was closely monitored and the storage interval between slurry sampling periods was similar. The amount of phosphorus contained in slurry from swine production facilities varies widely. The $0.15 \mathrm{~g} \mathrm{~kg}^{-1}$ of TP in the slurry obtained from the pull-plug waste management system used in this investigation was within the lower range of those typically found in the industry. As a result, the amount of TP applied to the experimental plots was also relatively small, even at the higher $\mathrm{N}$ application rates. Thus, the amount of TP transported in runoff was also relatively small and did not vary significantly among the varying $\mathrm{N}$ application rates.

Gilley et al. (2007b) conducted a field study to measure nutrient transport in runoff as affected by tillage and time following the application of swine slurry to a site on which corn was grown. The rainfall simulation and runoff collection procedures used by Gilley et al. (2007b) were similar to those used in the present investigation. The swine slurry that was used was obtained from a deep pit located below a slatted floor and had a TP content of $1.01 \mathrm{~g} \mathrm{~kg}^{-1}$, which was much larger than the $0.15 \mathrm{~g} \mathrm{~kg}^{-1}$ used in the present investigation. The slurry used by Gilley et al.

Table 1. Effects of a grass hedge and nitrogen application rate on nutrient loads averaged over three rainfall simulation runs. ${ }^{\text {[a] }}$

\begin{tabular}{|c|c|c|c|c|c|c|c|c|c|c|}
\hline & $\begin{array}{c}\text { DP } \\
\left(\mathrm{kg} \mathrm{ha}^{-1}\right)\end{array}$ & $\begin{array}{c}\mathrm{PP} \\
\left(\mathrm{kg} \mathrm{ha}^{-1}\right)\end{array}$ & $\begin{array}{c}\mathrm{TP} \\
\left(\mathrm{kg} \mathrm{ha}^{-1}\right)\end{array}$ & $\begin{array}{c}\mathrm{NO}_{3}-\mathrm{N} \\
\left(\mathrm{kg} \mathrm{ha}^{-1}\right)\end{array}$ & $\begin{array}{c}\mathrm{NH}_{4}-\mathrm{N} \\
\left(\mathrm{kg} \mathrm{ha}^{-1}\right)\end{array}$ & $\begin{array}{c}\mathrm{TN} \\
\left(\mathrm{kg} \mathrm{ha}^{-1}\right)\end{array}$ & $\begin{array}{c}\mathrm{EC} \\
\left(\mathrm{dS} \mathrm{m}^{-1}\right)\end{array}$ & $\mathrm{pH}$ & $\begin{array}{c}\text { Runoff } \\
(\mathrm{mm})\end{array}$ & $\begin{array}{c}\text { Erosion } \\
\left(\mathrm{Mg} \mathrm{ha}^{-1}\right)\end{array}$ \\
\hline \multicolumn{11}{|l|}{ Grass hedge } \\
\hline Grass hedge & 0.03 & $0.16 \mathrm{a}$ & 0.19 & 0.83 & 0.11 & 1.01 & $0.73 \mathrm{~b}$ & $7.85 \mathrm{~b}$ & 14 & 0.11 \\
\hline No-grass hedge & 0.04 & $0.10 \mathrm{~b}$ & 0.14 & 0.81 & 0.27 & 0.88 & $0.78 \mathrm{a}$ & $8.16 \mathrm{a}$ & 15 & 0.17 \\
\hline \multicolumn{11}{|l|}{ Nitrogen application rate (year $\left.{ }^{-1}\right)$} \\
\hline 0 & $0.01 \mathrm{~b}$ & $0.18 \mathrm{a}$ & 0.19 & 0.93 & $0.01 \mathrm{~b}$ & 1.05 & $0.70 \mathrm{c}$ & 8.04 & 17 & 0.15 \\
\hline 1 & $0.04 \mathrm{a}$ & $0.14 \mathrm{ab}$ & 0.18 & 0.93 & $0.23 \mathrm{a}$ & 1.07 & $0.75 \mathrm{~b}$ & 8.00 & 16 & 0.13 \\
\hline 2 & $0.04 \mathrm{a}$ & $0.11 \mathrm{bc}$ & 0.15 & 0.76 & $0.21 \mathrm{a}$ & 0.89 & $0.76 \mathrm{~b}$ & 8.00 & 13 & 0.14 \\
\hline 3 & $0.05 \mathrm{a}$ & $0.08 \mathrm{c}$ & 0.13 & 0.67 & $0.32 \mathrm{a}$ & 0.77 & $0.80 \mathrm{a}$ & 7.98 & 12 & 0.13 \\
\hline ANOVA & \multicolumn{10}{|c|}{$\operatorname{Pr}>\mathrm{F}$} \\
\hline Grass hedge & 0.41 & 0.04 & 0.11 & 0.89 & 0.06 & 0.48 & 0.04 & 0.01 & 0.86 & 0.10 \\
\hline Nitrogen rate & 0.05 & 0.03 & 0.35 & 0.47 & 0.01 & 0.60 & 0.01 & 0.76 & 0.45 & 0.94 \\
\hline Grass hedge $\times$ Nitrogen rate & 0.63 & 0.47 & 0.45 & 0.88 & 0.20 & 0.85 & 0.35 & 0.89 & 0.85 & 0.99 \\
\hline
\end{tabular}

[a] Values in the same column followed by different letters are significantly different at the 0.05 probability level based on the LSD test. 


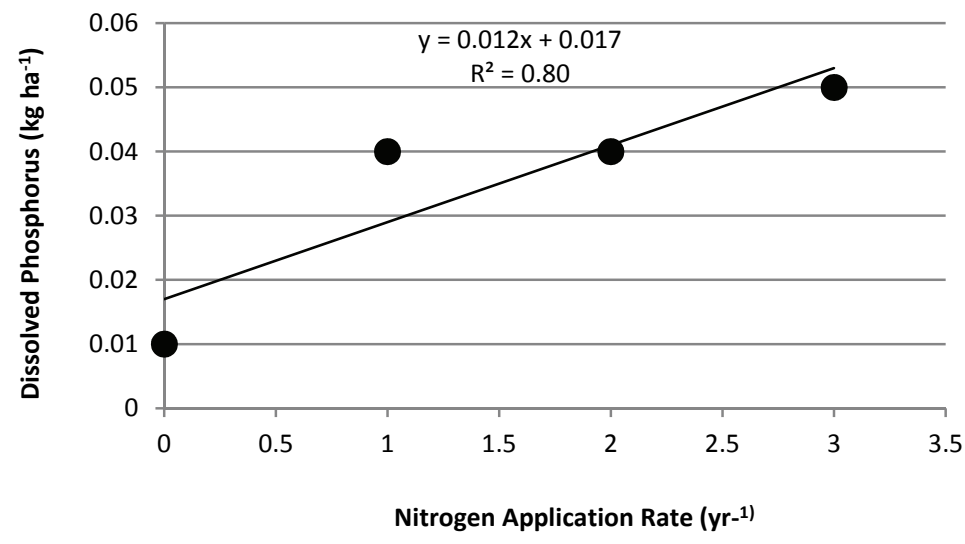

Figure 2. Dissolved phosphorus transport as affected by nitrogen application rate.

(2007b) was applied at a rate required to meet a 1 year $\mathrm{N}$ requirement for corn. For no-till conditions, the mean DP, $\mathrm{PP}$, and TP content of runoff measured 4 days following application were $0.23,0.12$, and $0.35 \mathrm{~kg} \mathrm{ha}^{-1}$, respectively, which were larger than the mean values of $0.04,0.10$, and $0.14 \mathrm{~kg} \mathrm{ha}^{-1}$ obtained in the present investigation for the nograss hedge condition. The relatively small $\mathrm{P}$ content of the slurry used in the present study is thought to have resulted in the smaller P load measurements.

\section{Nitrogen LOAD IN RUNOFF}

The grass hedge did not significantly reduce runoff loads of $\mathrm{NO}_{3}-\mathrm{N}, \mathrm{NH}_{4}-\mathrm{N}$, or $\mathrm{TN}$, which for the grass hedge were $0.83,0.11$, and $1.01 \mathrm{~kg} \mathrm{ha}^{-1}$, respectively (table 1 ). Increasing $\mathrm{N}$ application rate from a 1 year to a 3 year corn $\mathrm{N}$ requirement also did not result in a significant increase in $\mathrm{NO}_{3}-\mathrm{N}, \mathrm{NH}_{4}-\mathrm{N}$, or TN loads in runoff.

The $0.5 \mathrm{mg} \mathrm{kg}^{-1}$ of $\mathrm{NO}_{3}-\mathrm{N}$ in the swine slurry and the $11 \mathrm{mg} \mathrm{kg}{ }^{-1}$ of residual $\mathrm{NO}_{3}-\mathrm{N}$ in the soil at the time of slurry application were both relatively small. As a result, no significant differences in $\mathrm{NO}_{3}-\mathrm{N}$ loads in runoff were found between the check plots where no manure was applied and the plots on which swine slurry was added.

The $776 \mathrm{mg} \mathrm{ha}^{-1}$ of $\mathrm{NH}_{4}-\mathrm{N}$ contained in the swine slurry was much larger than the $\mathrm{NO}_{3}-\mathrm{N}$ content of $0.5 \mathrm{mg} \mathrm{ha}{ }^{-1}$. Therefore, runoff loads of $\mathrm{NH}_{4}-\mathrm{N}$ increased in a linear fashion with nitrogen application rate, and they were significantly larger on the plots where slurry was applied than on the check plots (fig. 3).

No significant differences in $\mathrm{TN}$ loads in runoff were found between the check plots where no manure was applied and the plots on which swine slurry was added (table 1). The TN content of the swine slurry obtained from the pull-plug waste management system was only $923 \mathrm{mg}$ $\mathrm{kg}^{-1}$. As a result, it was necessary to apply a relatively large amount of slurry to meet crop $\mathrm{N}$ requirements. Most of the slurry infiltrated into the soil profile following application, and only a small amount remained in the critical zone near the soil surface. As a result, TN loads in runoff were relatively small, even for the larger $\mathrm{N}$ application rates.

For no-till conditions, Gilley et al. (2007b) found that the mean $\mathrm{NO}_{3}-\mathrm{N}, \mathrm{NH}_{4}-\mathrm{N}$, and $\mathrm{TN}$ content of runoff measured 4 days following swine slurry application were $2.72,0.47$, and $4.58 \mathrm{~kg} \mathrm{ha}^{-1}$, respectively. These values were larger than the $0.81,0.27$, and $1.08 \mathrm{~kg} \mathrm{ha}^{-1}$ measured in the present study for the no-grass hedge condition. The $\mathrm{NH}_{4}-\mathrm{N}$ and $\mathrm{TN}$ content of the swine slurry applied by Gilley et al. (2007b) were 4.07 and $5.82 \mathrm{~g} \mathrm{~kg}^{-1}$, respectively, which were substantially larger than 0.78 and $0.92 \mathrm{~g} \mathrm{~kg}^{-1}$ used in the present study.

\section{MEASUREMENTS OF EC, pH, RuNOFF, AND SOIL LoSS}

The grass hedge significantly reduced EC measurements from 0.78 to $0.73 \mathrm{dS} \mathrm{m}^{-1}$ (table 1). Chemical constituents in

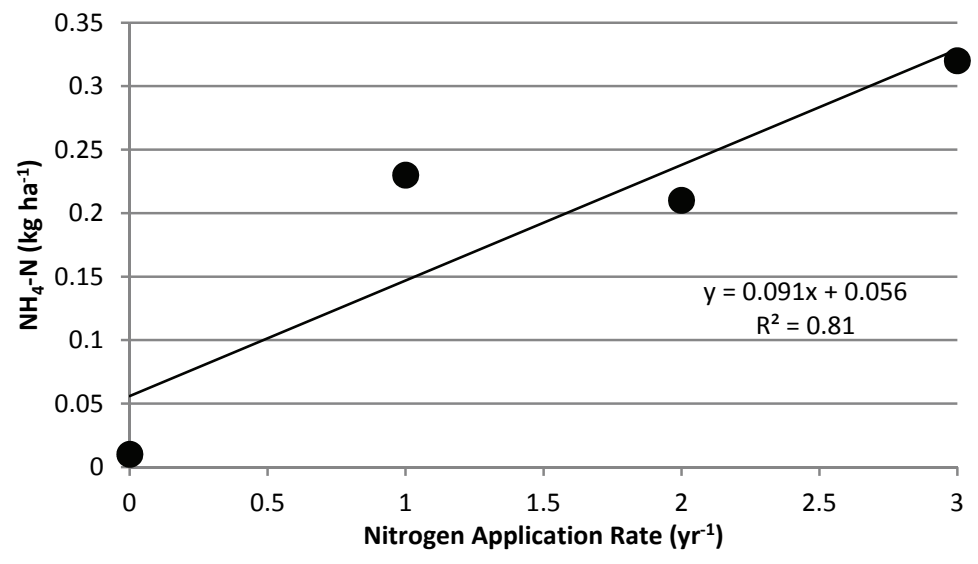

Figure 3. $\mathrm{NH}_{4}-\mathrm{N}$ transport as affected by nitrogen application rate. 


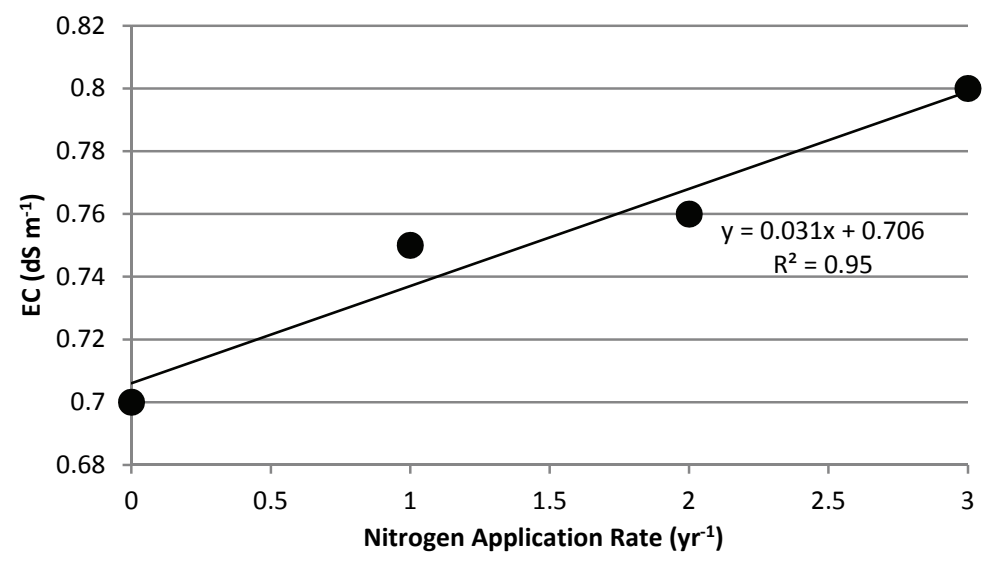

Figure 4. Electrical conductivity (EC) as affected by nitrogen application rate.

the runoff appeared to have been adsorbed by soil or vegetative materials contained within the grass hedge. Nitrogen application rate also significantly influenced EC measurements. As slurry application rate increased from a 0 to 3 year corn $\mathrm{N}$ requirement, $\mathrm{EC}$ values significantly increased in a linear fashion from 0.70 to $0.80 \mathrm{dS} \mathrm{m}^{-1}$ (table 1; fig. 4).

The $\mathrm{pH}$ value of 7.85 measured on the grass hedge treatment was significantly less than the 8.16 value obtained for the no-grass hedge condition (table 1). The rate of water movement over the plots containing a grass hedge would be expected to be less than on the no-grass hedge treatment. Chemical constituents contained within the grass hedge may have reacted with the relatively slowmoving runoff to reduce $\mathrm{pH}$ values. Nitrogen application rate did not significantly affect $\mathrm{pH}$ measurements.

Water was added to the plots just before the rainfall simulation tests began to provide more uniform antecedent soil water conditions among experimental treatments. As a result, no significant differences in runoff amounts were found between the grass hedge and no-grass hedge treatments (table 1).

Although the grass hedge reduced erosion from 0.17 to $0.11 \mathrm{Mg} \mathrm{ha}^{-1}$, the difference was not statistically significant (table 1). The area above the grass hedge had been farmed using a no-till management system and contained a substantial residue cover, which caused relatively small soil loss rates. A grass hedge is less effective in reducing soil loss when small amounts of sediment are present in runoff.

Gilley et al. (2007b) found that for no-till conditions the mean $\mathrm{EC}$ and $\mathrm{pH}$ of runoff measured 4 days following swine slurry application were $0.85 \mathrm{dS} \mathrm{m}^{-1}$ and 7.31, respectively. In the present study, $\mathrm{EC}$ and $\mathrm{pH}$ values for the no-grass hedge condition were $0.78 \mathrm{dS} \mathrm{m}^{-1}$ and 8.16, respectively. The smaller nutrient content values of the slurry used in the present investigation resulted in smaller $\mathrm{EC}$ and larger $\mathrm{pH}$ values for runoff.

\section{RunOFF ChaRaCteristics as AFFECTED BY RUNOFF RATE}

Measuring the effects of flow rate on runoff characteristics provides information on the effects of narrow grass hedges on nutrient transport under varying hydrologic conditions. Because the upslope contributing area existing under field conditions is much larger than that provided by the $4.0 \mathrm{~m}$ long experimental plots, additional flow was introduced at the top of the plots to simulate greater plot lengths. Rainfall intensity and duration are both highly variable. By relating nutrient load to flow rate, the experimental results are applicable to a larger range of rainfall and runoff conditions.

Capturing and storing all of the runoff that occurred during the experimental tests where simulated overland flow was introduced was not practical. Therefore, nutrient and sediment samples were collected under steady-state runoff conditions, and nutrient load values per unit time are reported for this portion of the study.

\section{Phosphorus Measurements}

A significant grass hedge $\times$ runoff rate interaction was found for the DP transport rate. The presence of a grass hedge and nitrogen application rate did not significantly affect transport rates for PP or TP (table 2). The rates of transport of DP, PP, and TP were each influenced by runoff rate, and they increased in a linear fashion from 7 to 25,65 to 357 , and 72 to $382 \mathrm{~g} \mathrm{ha}^{-1} \mathrm{~min}^{-1}$, respectively (table 2 ; fig. 5). It is apparent from figure 5 that the contribution of DP to TP load rates was relatively small.

Gilley et al. (2008b) conducted a field study to measure the effects of overland flow rate on nutrient transport following the application of swine slurry to plots containing varying amounts of corn residue. The plots were either disked or maintained in a no-till condition following slurry application. The rainfall simulation and runoff collection procedures used by Gilley et al. (2008b) were similar to those used in the present investigation. The swine slurry used by Gilley et al. (2008b) was obtained from a deep pit located below a slatted floor and had a TP content of $1.01 \mathrm{~g} \mathrm{~kg}^{-1}$, which was much larger than the $0.15 \mathrm{~g} \mathrm{~kg}^{-1}$ used in the present investigation. The slurry was applied at a rate required to meet a 1 year $\mathrm{N}$ requirement for corn. The mean DP, PP, and TP load rates measured by Gilley et al. (2008b) for conditions where inflow was added varied from 41 to 52 , 50 to 169 , and 92 to $220 \mathrm{~g} \mathrm{ha}^{-1} \mathrm{~min}^{-1}$, respectively, while mean values of 7 to 25,65 to 357 , and 72 to $382 \mathrm{~g} \mathrm{ha}^{-1} \mathrm{~min}^{-1}$ were obtained in the present investigation. 
Table 2. Runoff water quality parameters as affected by a grass hedge, nitrogen application rate, and runoff rate. ${ }^{[a]}$

\begin{tabular}{|c|c|c|c|c|c|c|c|c|c|}
\hline & $\begin{array}{c}\text { DP } \\
\left(\mathrm{g} \mathrm{ha}^{-1}\right. \\
\left.\mathrm{min}^{-1}\right)\end{array}$ & $\begin{array}{c}\text { PP } \\
\left(\mathrm{g} \mathrm{ha}^{-1}\right. \\
\left.\min ^{-1}\right)\end{array}$ & $\begin{array}{c}\mathrm{TP} \\
\left(\mathrm{g} \mathrm{ha}^{-1}\right. \\
\left.\mathrm{min}^{-1}\right)\end{array}$ & $\begin{array}{c}\mathrm{NO}_{3}-\mathrm{N} \\
\left(\mathrm{g} \mathrm{ha}^{-1}\right. \\
\left.\mathrm{min}^{-1}\right)\end{array}$ & $\begin{array}{l}\mathrm{NH}_{4}-\mathrm{N} \\
\left(\mathrm{g} \mathrm{ha}^{-1}\right. \\
\left.\min ^{-1}\right)\end{array}$ & $\begin{array}{c}\mathrm{TN} \\
\left(\mathrm{g} \mathrm{ha}^{-1}\right. \\
\left.\min ^{-1}\right)\end{array}$ & $\begin{array}{c}\mathrm{EC} \\
\left(\mathrm{dS} \mathrm{m} \mathrm{m}^{-1}\right)\end{array}$ & $\mathrm{pH}$ & $\begin{array}{c}\text { Soil Loss } \\
\left(\mathrm{kg} \mathrm{ha}^{-1}\right. \\
\left.\mathrm{min}^{-1}\right)\end{array}$ \\
\hline \multicolumn{10}{|l|}{ Grass hedge } \\
\hline Grass hedge & 16 & 265 & 281 & 766 & 23 & 959 & 0.74 & 7.89 & 33.6 \\
\hline No-grass hedge & 16 & 105 & 121 & 682 & 56 & 766 & 0.75 & 8.01 & 32.9 \\
\hline \multicolumn{10}{|l|}{ Nitrogen application rate $\left(\right.$ year $\left.^{-1}\right)$} \\
\hline 0 & 17 & 344 & 361 & 1030 & 19 & 1260 & 0.73 & 7.97 & 49.0 \\
\hline 1 & 13 & 124 & 137 & 608 & 31 & 698 & 0.74 & 7.96 & 26.4 \\
\hline 2 & 15 & 132 & 147 & 622 & 47 & 733 & 0.74 & 7.91 & 25.8 \\
\hline 3 & 19 & 142 & 161 & 640 & 63 & 763 & 0.75 & 7.97 & 31.9 \\
\hline \multicolumn{10}{|l|}{ Runoff rate $\left(\mathrm{L} \mathrm{min}^{-1}\right)$} \\
\hline 3.6 & $7 \mathrm{~d}$ & $65 \mathrm{~b}$ & $72 \mathrm{c}$ & $273 \mathrm{~b}$ & $30 \mathrm{c}$ & $323 \mathrm{~d}$ & $0.75 \mathrm{a}$ & $8.09 \mathrm{a}$ & $15.0 \mathrm{~d}$ \\
\hline 8.5 & $13 \mathrm{c}$ & $123 \mathrm{~b}$ & $136 \mathrm{bc}$ & $568 \mathrm{~b}$ & $40 \mathrm{~b}$ & $644 \mathrm{c}$ & $0.74 \mathrm{~b}$ & $7.99 \mathrm{~b}$ & $27.3 \mathrm{c}$ \\
\hline 13.7 & $19 \mathrm{~b}$ & $196 \mathrm{~b}$ & $215 b$ & $852 \mathrm{ab}$ & $47 \mathrm{a}$ & $993 \mathrm{~b}$ & $0.74 \mathrm{~b}$ & $7.89 \mathrm{c}$ & $39.6 \mathrm{~b}$ \\
\hline 19.7 & $25 \mathrm{a}$ & $357 \mathrm{a}$ & $382 \mathrm{a}$ & $1204 \mathrm{a}$ & $43 a b$ & $1490 \mathrm{a}$ & $0.74 \mathrm{~b}$ & $7.83 \mathrm{~d}$ & $51.2 \mathrm{a}$ \\
\hline ANOVA & \multicolumn{9}{|c|}{$\operatorname{Pr}>F$} \\
\hline Grass hedge & 0.91 & 0.27 & 0.29 & 0.76 & 0.16 & 0.61 & 0.12 & 0.38 & 0.95 \\
\hline Nitrogen rate & 0.77 & 0.48 & 0.49 & 0.50 & 0.44 & 0.54 & 0.19 & 0.42 & 0.38 \\
\hline Runoff rate & 0.01 & 0.01 & 0.01 & 0.01 & 0.01 & 0.01 & 0.01 & 0.01 & 0.01 \\
\hline Grass hedge $\times$ nitrogen rate & 0.89 & 0.46 & 0.46 & 0.36 & 0.98 & 0.43 & 0.68 & 0.85 & 0.34 \\
\hline Grass hedge $\times$ runoff rate & 0.01 & 0.11 & 0.11 & 0.16 & 0.63 & 0.18 & 0.01 & 0.24 & 0.14 \\
\hline Nitrogen rate $\times$ runoff rate & 0.99 & 0.50 & 0.51 & 0.79 & 0.78 & 0.57 & 0.02 & 0.61 & 0.80 \\
\hline $\begin{array}{l}\text { Grass hedge } \times \text { nitrogen rate } \\
\times \text { runoff rate }\end{array}$ & 0.68 & 0.48 & 0.49 & 0.39 & 0.22 & 0.43 & 0.85 & 0.81 & 0.49 \\
\hline
\end{tabular}

[a] Values in the same column followed by different letters are significantly different at the 0.05 probability level based on the LSD test.

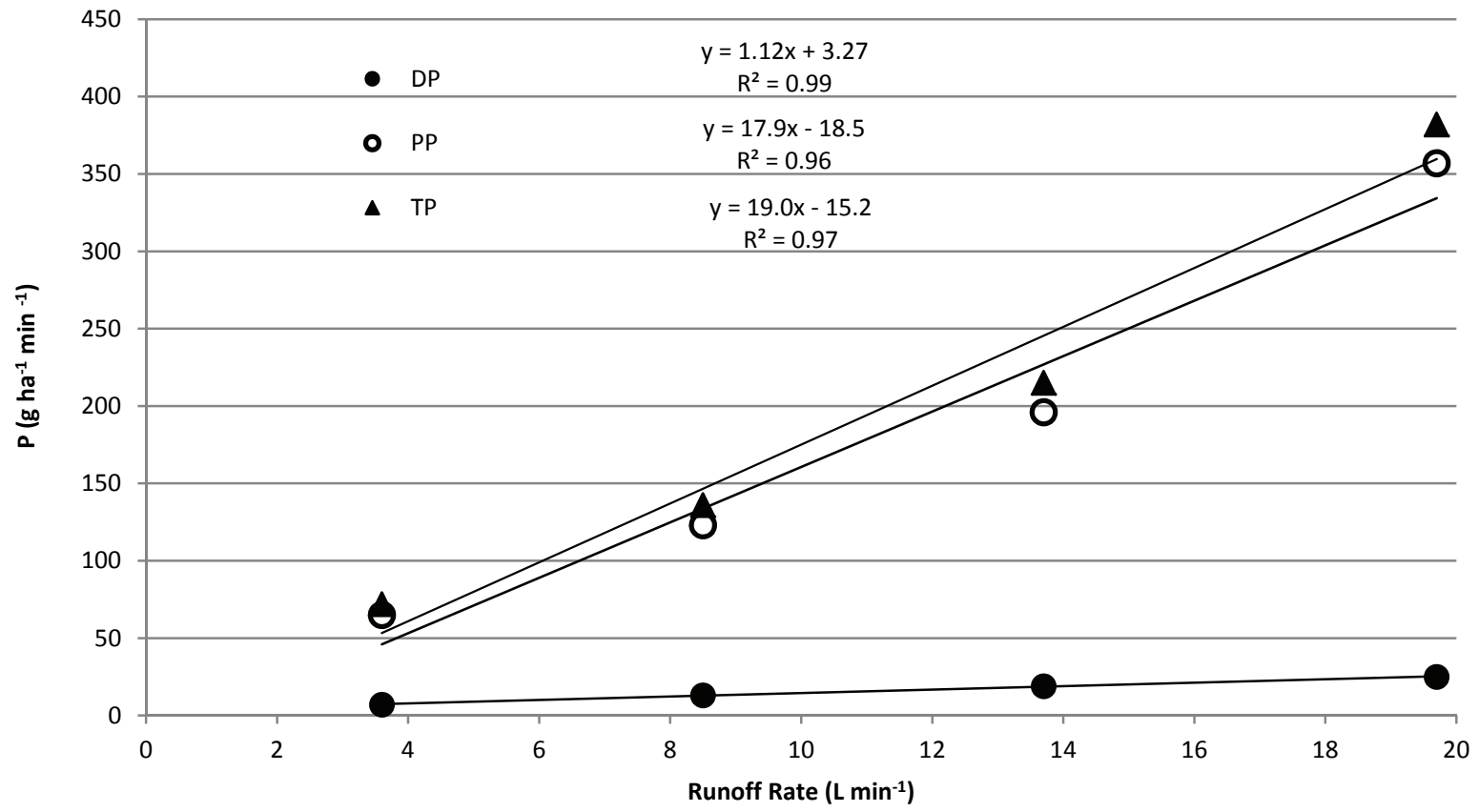

Figure 5. Dissolved phosphorus (DP), particulate phosphorus (PP), and total phosphorus (TP) transport rate as affected by runoff rate.

\section{Nitrogen Measurements}

Transport rates for $\mathrm{NO}_{3}-\mathrm{N}, \mathrm{NH}_{4}-\mathrm{N}$, and $\mathrm{TN}$ were not significantly affected by a grass hedge or nitrogen application rate. However, rates of transport of $\mathrm{NO}_{3}-\mathrm{N}$, $\mathrm{NH}_{4}-\mathrm{N}$, and $\mathrm{TN}$ were each significantly affected by runoff rate and varied in a linear fashion from 273 to 1204,30 to 47 , and 323 to $1490 \mathrm{~g} \mathrm{ha}^{-1} \mathrm{~min}^{-1}$, respectively (table 2; fig. 6).
Gilley et al. (2008b) found that the mean $\mathrm{NO}_{3}-\mathrm{N}, \mathrm{NH}_{4}$ $\mathrm{N}$, and TN transport rates for conditions where inflow was added varied from 573 to 2280,36 to 47 , and 609 to $2330 \mathrm{~g}$ $\mathrm{ha}^{-1} \mathrm{~min}^{-1}$, respectively, compared to the values of 273 to 1204,30 to 47 , and 323 to $1490 \mathrm{~g} \mathrm{ha}^{-1} \mathrm{~min}^{-1}$ obtained in the present study. The $\mathrm{NH}_{4}-\mathrm{N}$ and $\mathrm{TN}$ content of the swine slurry applied by Gilley et al. (2008b) were 4.07 and $5.82 \mathrm{~g}$ $\mathrm{kg}^{-1}$, respectively, which were substantially larger than the 0.78 and $0.92 \mathrm{~g} \mathrm{~kg}^{-1}$ used in the present study. 


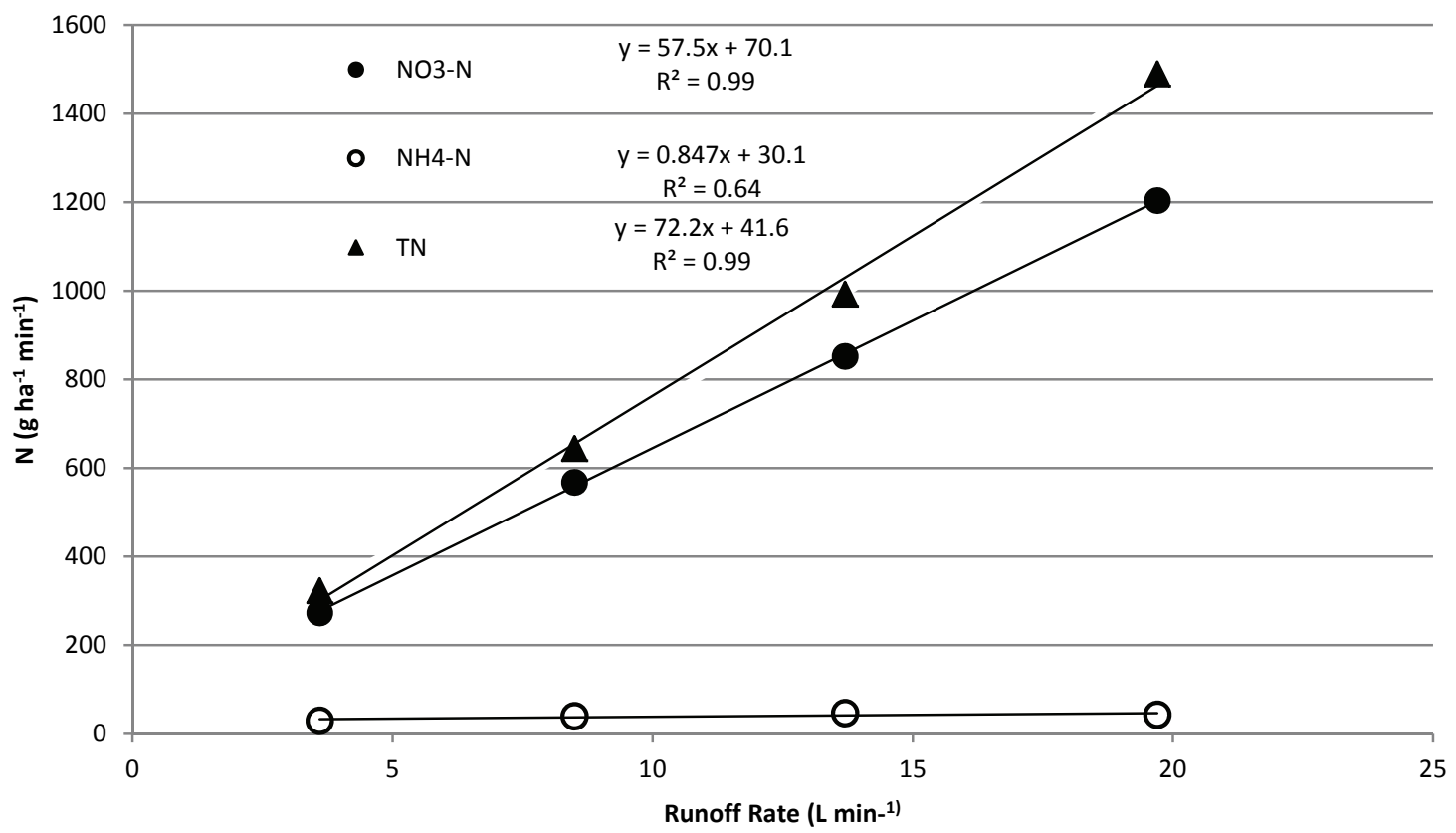

Figure 6. $\mathrm{NO}_{3}-\mathrm{N}, \mathrm{NH}_{4}-\mathrm{N}$, and total nitrogen (TN) transport rate as affected by runoff rate.

\section{$E C, p H$, and Soil Loss Measurements}

A grass hedge $\times$ runoff rate and a nitrogen application rate $\times$ runoff rate interaction were found for EC (table 2). Values for $\mathrm{pH}$ and soil loss were not significantly affected by the presence of a grass hedge. However, runoff rate significantly affected $\mathrm{pH}$ values, which decreased in a linear fashion with runoff rate and varied from 7.83 to 8.09 (table 2; fig. 7).

Soil loss values increased in a linear fashion with runoff rate and varied from 15.0 to $51.2 \mathrm{~kg} \mathrm{ha}^{-1} \mathrm{~min}^{-1}$ (table 2; fig. 8). An increase in soil loss rate with runoff rate is well established. A substantial amount of crop residue was present on the soil surface, since the study site had been cropped under a long-term no-till management system and corn had been seeded the previous year. In the absence of concentrated flow, raindrop impact is the principal mechanism providing soil particles for transport by overland flow. Sediment transport mechanisms appeared to have influenced interrill erosion at the study location (Gilley et al. 1985a, 1985b).

\section{Conclusions}

When swine slurry containing relatively low nutrient values was applied, narrow grass hedges did not significantly reduce runoff loads of DP, PP, TP, $\mathrm{NO}_{3}-\mathrm{N}$, $\mathrm{NH}_{4}-\mathrm{N}$, and $\mathrm{TN}$ for conditions both with and without the introduction of simulated overland flow. The loads of DP, PP, TP, $\mathrm{NO}_{3}-\mathrm{N}, \mathrm{NH}_{4}-\mathrm{N}$, and $\mathrm{TN}$ in runoff also were not significantly influenced by manure application rate. However, runoff rate significantly influenced each of the measured water quality parameters.

Most of the nutrients contained in swine slurry are dissolved. Following application, the slurry along with the dissolved constituents infiltrate into the soil profile, and only a small amount of the slurry remained within the

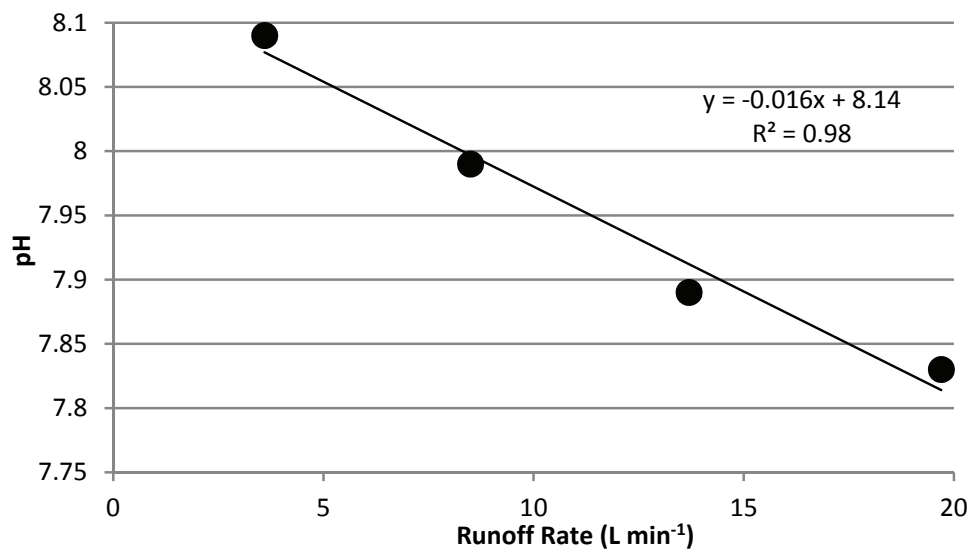

Figure 7. pH values as affected by runoff rate. 


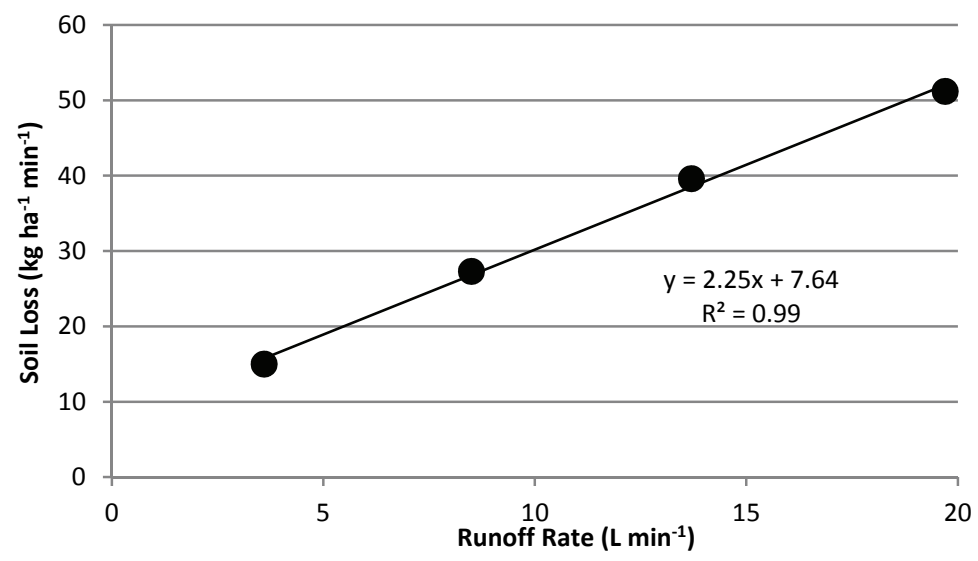

Figure 8. Soil loss rate as affected by runoff rate.

critical zone near the soil surface. As a result, the narrow grass hedge did not significantly reduce runoff nutrient transport following slurry application.

\section{REFERENCES}

Blanco-Canqui, H., C. J. Gantzer, S. H. Anderson, and E. E. Alberts. 2004a. Grass barriers for reduced concentrated flow induced soil and nutrient loss. SSSA J. 68(6): 1963-1972.

Blanco-Canqui, H., C. J. Gantzer, S. H. Anderson, E. E. Alberts, and A. L. Thompson. 2004b. Grass barrier and vegetative filter strip effectiveness in reducing runoff, sediment, nitrogen, and phosphorus loss. SSSA J. 68(5): 1670-1678.

Blanco-Canqui, H., C. J. Gantzer, and S. H. Anderson. 2006. Performance of grass barriers and filter strips under interrill and concentrated flow. J. Environ. Qual. 35(6): 1969-1974.

Dabney, S. M., L. D. Meyer, W. C. Harmon, C. V. Alonso, and G. R. Foster. 1995. Depositional patterns of sediment trapped by grass hedges. Trans. ASAE 38(6): 1719-1729.

Dabney, S. M., Z. Liu, M. Lane, J. Douglas, J. Zhu, and D. C. Flanagan, 1999. Landscape benching from tillage erosion between grass hedges. Soil Tillage Res. 51(3): 219-231.

Dewald, C., J. Henry, S. Bruckerhoff, J. Ritchie, D. Shepard, J. Douglas, and D. Wolfe. 1996. Guidelines for the establishment of warm season grass hedge for erosion control. J. Soil Water Cons. 51(1): 16-20.

Eghball, B., and J. F. Power. 1994. Beef cattle feedlot manure management. J. Soil Water Cons. 49(2): 113-122.

Eghball, B, J. E. Gilley, L. A. Kramer, and T. B. Moorman. 2000. Narrow grass hedge effects on phosphorus and nitrogen in runoff following manure and fertilizer application. J. Soil Water Cons. 55(2): 172-176.

Eghball, B., B. J. Wienhold, J. E. Gilley, and R. A. Eigenberg. 2002. Mineralization of manure nutrients. J. Soil Water Cons. 57(6): 470-473.

Gilbertson, C. B., F. A. Norstadt, A. C. Mathers, R. F. Holt, L. R. Shuyler, A. P. Barnett, T. M. McCalla, C. A. Onstad, R. A. Young, L. A. Christenson, and D. L. Van Dyne. 1979. Animal waste utilization on cropland and pastureland: A manual for evaluating agronomic and environmental effects. Utilization Research Report No. 6. Washington, D.C.: USDA.

Gilley, J. E., and L. M. Risse. 2000. Runoff and soil loss as affected by the application of manure. Trans. ASAE 43(6): 1583-1588.

Gilley, J. E., D. A. Woolhiser, and D. B. McWhorter. 1985a. Interrill soil erosion: Part I. Development of model equations. Trans ASAE 28(1): 147-153, 159.

Gilley, J. E., D. A. Woolhiser, and D. B. McWhorter. 1985b. Interrill soil erosion: Part II. Testing and use of model equations. Trans ASAE 28(1): 154-159.

Gilley, J. E., B. Eghball, and D. B. Marx. 2007a. Nitrogen and phosphorus concentrations of runoff as affected by moldboard plowing. Trans. ASABE 50(5): 1543-1548.

Gilley, J. E., B. Eghball, and D. B. Marx. 2007b. Nutrient concentrations of runoff during the year following manure application. Trans. ASABE 50(6): 1987-1999.

Gilley, J. E., B. Eghball, and D. B. Marx. 2008a. Narrow grass hedge effects on nutrient transport following compost application. Trans. ASABE 51(3): 997-1005.

Gilley, J. E., W. F. Sabatka, B. Eghball, and D. B. Marx. 2008b. Nutrient transport as affected by rate of overland flow. Trans. $A S A B E$ 51(4): 1287-1293.

Gilley, J. E., L. M. Durso, R. A. Eigenberg, D. B. Marx, and B. L. Wodbury. 2011. Narrow grass hedge control of nutrient loads following variable manure applications. Trans. ASABE 54(3): 847-855.

Humphry, J. B., T. C. Daniel, D. R. Edwards, and A. N. Sharpley. 2002. A portable rainfall simulator for plot-scale runoff studies. Applied Eng. in Agric. 18(2): 199-204.

Jin, C. X., and M. J. M. Romkens. 2000. Experimental studies of factors in determining sediment trapping in vegetative filter strips. Trans. ASAE 44(2):277-288.

Johnson, C. M., and A. Ulrich. 1959. Analytical methods for use in plant analysis. Agricultural Experiment Station Bulletin 766. Berkeley, Cal.: University of California.

Kemper, D., S. Dabney, L. Kramer, D. Dominick, and T. Keep. 1992. Hedging against erosion. J. Soil Water Cons. 47(4): 284288.

Kettler, T. A., J. W. Doran, and T. L. Gilbert. 2001. Simplified method for soil particle-size determination to accompany soilquality analyses. SSSA J. 65(3): 849-852.

Laflen, J. M., W. J. Elliot, J. R. Simanton, C. S Holzhey, and K. D. Kohl. 1991. WEPP soil erodibility experiments for rangeland and cropland soils. J. Soil Water Cons. 46(1): 39-44.

Meyer, L. D., S. M. Dabney, and W. C. Harmon. 1995. Sedimenttrapping effectiveness of stiff-grass hedges. Trans. ASAE 38(3): 809-815.

Monke, E. J., H. J. Marelli, L. D. Meyer, and J. F. Dejong. 1977. Runoff, erosion, and nutrient movement from interrill areas. Trans. ASAE 20(1): 58-61.

Murphy, J., and J. P. Riley. 1962. A modified single-solution method for the determination of phosphate in natural waters. Anal. Chem. Acta 27: 31-36.

Owino, J. O., S. F. O. Owido, and M. C. Chemelil. 2006. Nutrients in runoff from a clay loam soil protected by narrow grass strips. Soil Tillage Res. 88(1): 116-122. 
Rachman, A., S. H. Anderson, C. J. Gantzer, and E. E. Alberts. 2004a. Soil hydraulic properties influenced by stiff-stemmed grass hedge systems. SSSA J. 68(4): 1386-1393.

Rachman, A., S. H. Anderson, C. J. Gantzer, and A. L. Thompson. $2004 \mathrm{~b}$. Influence of stiff-stemmed grass hedge systems on infiltration. SSSA J. 68(6): 2000-2006.

Renard, K. G., G. R. Foster, G. A. Weesies, D. K. McCool, and D. C. Yoder. 1997. Predicting soil erosion by water: A guide to conservation planning with the Revised Universal Soil Loss Equation (RUSLE). Agriculture Handbook 703. Washington, D.C.: USDA.
SAS. 2011. SAS/STAT User's Guide. Version 9.3. Vol. 1. 4th ed. Cary, N.C.: SAS Institute, Inc.

Sharpley, A. N., and P. J. A. Kleinman. 2003. Effect of rainfall simulator and plot scale on overland flow and phosphorus transport. J. Environ. Qual. 32(6): 2172-2179.

Tate, D. F. 1994. Determination of nitrogen in fertilizer by combustion: Collaborative study. J. AOAC Intl. 77(4): 829-839.

USDA-NRCS. 2010. Vegetative barrier. Conservation Practice Standard 601. Washington, D.C.: USDA Natural Resources Conservation Service. 